\title{
Digital Wallet and Mobile Banking Adoption Among Rural Bank Customer
}

\author{
Santosh Parakh ${ }^{1}$, Prakash Ukhalkar², Leena Sanu ${ }^{3}$ \\ 1. Vidya Pratishthan's Institute of Information Technology (VIIT), Baramati, Maharashtra 413133, India \\ 2. Pimpri Chinchwad College of Engineering, Pune, Maharashtra, Sector -26, Pradhikaran, Nigdi, Near Akurdi Railway Station, Pune - 411044 , India \\ 3. Christ College, Pune, Maharashtra, 26/4 A, Off Pune Nagar Road, Opposite Weikfield IT Citi Info Park, Wadgaon Sheri, Pune, Maharashtra 411014, \\ India
}

\section{ARTICLE INFO}

\section{Keywords:}

Digital Wallet,

Mobile Banking,

Rural Customer,

Adoption Factors

Kata kunci:

Dompet digital,

Perbankan Selular,

Pelanggan pedesaan,

Faktor-faktor adopsi

\section{A B S T R A C T}

This study provides a rural viewpoint to the global research and literature on adoption of digital wallet and mobile banking among rural customer. It empirically examines the most influencing factors that stimulating to digital wallet and mobile banking user for service adoption. Primary and secondary data sources are used. A sample of 300 customers was surveyed from the rural areas of Maharashtra state, INDIA. A Simple Random Sampling method is used for selections of area from Maharashtra state and Chi-square testing was used in stated hypothesis. The study concludes that Security-Privacy, Trust and Familiarity has significant impact on Mobile banking adoption. And qualitative factors such has Prestige, Speed, Trust, Safety \& Security, Easiness and Familiarity has major influence on rural customer for the adopting of Digital Wallet and Mobile banking services offered from financial institution.

\section{SARI PATI}

Studi ini memberikan sudut pandang pedesaan untuk penelitian dan literatur global tentang adopsi dompet digital dan perbankan seluler di antara pelanggan pedesaan. Penelitian ini secara empiris mempelajari faktor-faktor yang paling mempengaruhi dan mendorong pengguna mengadopsi layanan dompet digital dan mobile banking. Sumber data primer dan sekunder digunakan. Sampel 300 pelanggan disurvei dari daerah perdesaan di negara bagian Maharashtra, India. Metode Simple Random Sampling digunakan untuk pemilihan area di Maharashtra dan pengujian Chi-square digunakan untuk hipotesis yang dinyatakan. Studi tersebut menyimpulkan bahwa Keamanan-Privasi, Kepercayaan, dan Keakraban memiliki dampak signifikan pada adopsi perbankan Seluler. Dan faktor kualitatif seperti Prestige, Speed, Trust, Safety \& Security, Easiness and Familiarity berpengaruh besar pada nasabah perdesaan dalam mengadopsi layanan dompet digital dan mobile banking yang ditawarkan dari lembaga keuangan. 


\section{INTRODUCTION}

Delivery of digital services to the door step of customer at his place which may be office or home by using electronic technology can be termed as Mobile Banking. There are number of financial institutes and pressurized banks whose main intension is to attract the customers and improve customer's perception by introducing many alternate delivery channels. Most of the financial institutions such as Banks, Finance companies etc. have implemented variety of digital services such as e-banking, wallets, banking services, account statements etc. with more convenience for accessing account information and implementing transactions.

Specifically in the Asian region, demographic characteristics such as age, educational qualification, gender, marital status, employment status, income level, and locality have been found to influence the behaviors of Digital wallet and Mobile banking (MB) customers. There has been a significant development in the financial and banking institutions over the last 20 years because of the improvement information communication technology. Rapid growth and innovation in the Information Technology have continued to revolutionize the banking and financial industries. In the current decade, we are witnessed that digital wallet and mobile banking services has been broadly used, and an understanding of the customer adoption process will have important implications for every financial institution. Most of the studies found an importance of a rural customer. It can be assumed that rural customer is a backbone of an Indian economy. Now it is very important to shift more focus on understanding perception of rural customer on every segment of a business. This study aims to identify qualitative factors which stimulates a rural bank customer for the adoption of Mobile banking service.

\section{LITERATURE REVIEW}

Parakh \& Barbole (2013) examined consumers' perspective on internet banking adoption from western Maharashtra. Some adoptions and nonadoptions factors were investigated to understand consumers' focus on technology adoption. Study found that there is a huge gap between customer and service provider for motivating use of financial digital services. Research concluded that majority of consumer's are adoption digital services because they feel that it is reliable, convenient, user friendly and safe. For this research quantitative and qualitative parameters were taken into consideration.

Perkins et al. (2013) studied the factors affecting the adoption of online banking in Ghana and they found that all the factors such as Perceived Usefulness, Perceived Ease of Use, Government Support, Trust and Security have a direct and positive influence on Ghana's customer's intention to use internet banking. Study suggested to the bank managers to give concentration on the promotional and advancement on the priceless paybacks to gain more digital banking adopters in Ghana. To identify predictable results on adoption process, the scope of study should be increased by considering other important internet banking adoption factors. Based on the qualitative data collected for this study it is found that Government of Ghana shown a lot of support for digital banking services over last few years but still awareness about internet banking and digital wallet among the customer is not meet as it was initially expected.

Mohan et al (2013) evaluated causes of internet banking purpose in Malaysia by using TAM and TRP model. The result of the study revel that as compared to self-efficacy and trust factor, PEOU is the main factor towards the use of internet banking service among the customers in Malaysia. The study also found that self- efficacy and trust are negatively correlated to each other with intention towards online banking. The scope of the study was very restricted due to time limit. Also the important factors such as security and privacy are not covered in this study which is very much 
important to identify the perception of customers. Study found very interesting result about relation of sex with internet banking adoption and researchers found that there is more number of female internet banking users than male banking customers. In Malaysia, media reference has a significant impact on intention towards internet banking usage.

Giordani (2012) has examined electronic banking in Greece. The study was aimed to identify the adoption of digital banking services offered by commercial banks in Greece. Study found that higher education and income level are directly proportional to the adoption of internet banking in Greece. Especially homeowner peoples avoid for internet banking because of complexity in the online transactions and some other online banking issues. Because of high electronic risk, Greek customers mostly prefer traditional way of baking that is branch banking transactions. The cost of using internet banking is very less as compared to the branch banking. The findings provide recommendations to the banks managers in the Greek that, they should improve customer relationship management by adoption latest CRM tools. By proper marketing campaigns and providing necessary awareness sessions about internet banking to their existing customer's internet banking adoption ratio about internet banking service can be increased.

Mansumitrchai and AL-Malkawi (2011) examined factors underlying the Internet Banking adoption among Mexican customers. Study focused on the innovation of delivering financial and digital wallet services through electronic media by using Rogers (1983) model. In the study two phases of research methods used such as qualitative and quantitative research methodologies. In Mexico, technological barrier was the first most important attribute for adoption of internet banking and second attribute was trust. Non adopters feels that internet banking is very difficult, complicated, confusing and very risky also. But adopters trusted on the security and privacy concerns provided by banks. Adopters prefers internet banking system in Mexico because to maintain life style and innovation in the services. Both adopters and non-adopters agreed that to carry internet banking services individuals requires lack of computer skills. Compatibility was the important attribute for internet naming adoption but reference group plays an important role too.

\section{METHODOLOGY AND DATA SOURCE}

The purpose of this study is to understand adoption of digital wallet and internet banking technology in detail and to study most influencing factors that forces to individual to adopt these services. This research falls into the category of Empirical. The data of digital wallet and mobile banking user is collected from defined sample area. Primary and Secondary data is collected from appropriate data sources. To accomplish the digital wallet and mobile banking adoption study, this research is based on the examination of various journals which belongs to the appropriate domain.

\section{Scope of the Study}

Researcher was intended to examine consumer's perception towards digital wallet and mobile banking adoption in rural areas of Maharashtra state. Maharashtra contains 35 states and it is at top position in various domain in India. Current population of Maharashtra is 130 Million. Researcher has surveyed mobile banking customers of private, nationalized and co-operative banks in rural areas of Maharashtra, INDIA. This study examines the problems of Mobile banking customers, consumer's opinion towards adoption of digital wallet and Mobile banking and identifying the important factors affecting on them.

\section{Selection of the Area}

The researcher used the simple random sampling method for the selection of sampling area from Maharashtra state. A simple random sampling is a type of probability sampling method. Researcher has long practiced various forms of random selection. Here the researcher selected Pune, Solapur, Nashik and Nagpur as rural areas of 
Maharashtra for this study purpose as per Simple Random Sampling method.

\section{Selection of the Samples}

In this research, to select sample area probability sampling method is used and to select sample respondent (digital wallet and mobile banking users) a non-probability sampling method was used from selected sample area i.e. rural areas of Maharashtra state. For this study researcher has used a convenience sampling method to select samples. Total digital wallet and mobile banking users is not known to anyone so, researcher has selected 300 sample respondents.

\section{Research Model}

Figure 7.1, illustrates the model used in this study. In this instrument researcher hypothesized three factors (i.e. Security and Privacy, Trust and Familiarity) which is as follows.

$\mathrm{H}_{1}$ : There is significant relationship between Security-Privacy \& adoption of digital wallet \& mobile banking.
$\mathrm{H}_{2}$ : There is significant relationship between Trust \& adoption of digital wallet \& mobile banking.

$\mathrm{H}_{3}$ : There is significant relationship between Familiarity \& adoption of digital wallet \& mobile banking.

Other factors such as Easiness, Saving, Fulfillment, Speed, Convenience, Prestige also considered for this study.

\section{DATA ANALYSIS AND DISCUSSION}

\section{Locality and gender of the respondents}

Locality and gender are the important indicators and characteristics of the respondents. Table 8.1 indicates that there were 300 respondents were chosen for the study and there were $75(25 \%)$ respondents from Pune region, 75(25\%) respondents from Solapur region, 75(25\%) respondents from Nashik region and $75(25 \%)$ respondents from Nagpur region; Equal respondents were selected from rural areas of selected districts from Maharashtra state. Distribution of the gender shown in Table 6.2. Most of mobile banking users $69 \%$ were male

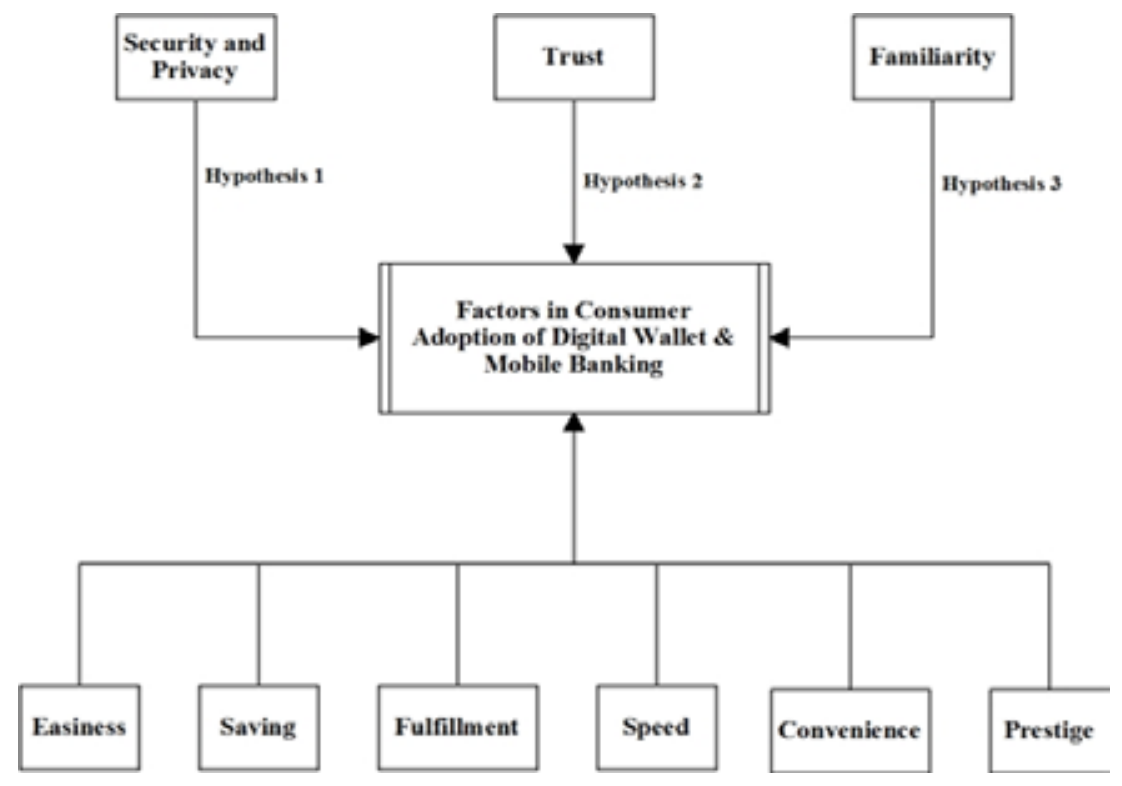

Figure 1. Research Model 
respondents and only $31 \%$ users were female. It indicates that most of the female bank customers are not using mobile banking services.

\section{Determinants of Digital Wallet and Mobile Banking} Adoption and Purposes of Using Mobile Banking. In the digital wallet and mobile banking literature many researchers have discussed about adoption of these services in different type of the customers and various demographic characteristics. Here researcher has addressed this issue based on their intensions of background of the respondents and their adoption of mobile banking service. Table from 8.3 indicates overall score and location wise score of the respondents given based on 5 point Likert Scale ranging from $1=$ Strongly Disagree to $5=$ Strongly. Agree higher value indicates their agreement and lower value that indicate disagreement while value 3 or about 3 indicates neutral response about the particular indicator.

For understanding the overall responses regarding Determinants of Adoption of Digital Wallet and Mobile Banking and purposes of using it, researcher has extracted mean value of the responses and data shows that (Table 8.3). Familiarity dimensions was ranging from 4.19 to 4.51, Security -Privacy dimension ranging from 4.11 to 4.37 , dimensions trust was ranging from 4.24 to 4.49 , dimension easiness was ranging from 3.56 to 3.96 , dimensions speed was ranging from 3.66 to 4.60 , dimensions prestige was 3.47 to 4.24 .

Tabel 1. Residence of the Respondents

\begin{tabular}{ccc}
\hline Locality & Freq. & Percentage \\
\hline Pune & 75 & 25 \\
\hline Solapur & 75 & 25 \\
\hline Nashik & 75 & 25 \\
\hline Nagpur & 75 & 25 \\
\hline Total & 300 & 100 \\
\hline
\end{tabular}

Tabel 2. Gender of the Respondents

\begin{tabular}{ccc}
\hline Gender & Freq. & Percentage \\
\hline Male & 208 & 69.3 \\
\hline Female & 92 & 31.7 \\
\hline Total & 300 & 100 \\
\hline
\end{tabular}

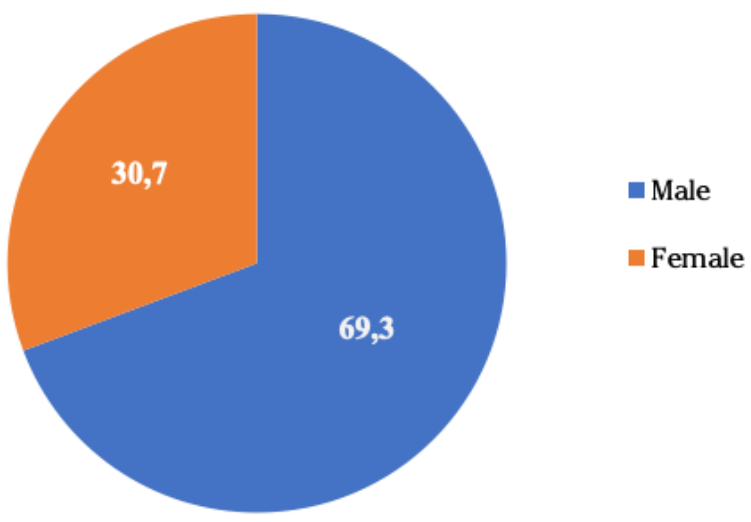

Figure 2. Respondent Gender Graph 
Overall results of mean analysis indicates that most of constructs and dimensions are ranging more than 3 hence we primarily say that all the dimensions have plays direct role in the adoption of digital wallet and mobile banking among the respondents from Pune, Solapur, Nashik and Nagpur.

\section{Bank wise distribution of the respondents}

A statistics of bank wise distribution of the respondents is essential to know more about the mobile banking users because this data clear the bank type wise distribution of the respondents chosen for the study. The study was not concentrated with any particular bank. Table 8.4 posited that there were more customers are nationalized bank (54.33\%) followed by private sector banks (40\%) followed by co-operative banks (5.67\%). Table 8.4 illustrates banks wise responses received from sample area.

Tabel 3. Determinants of Adoption of Digital Wallet and Mobile Banking and Purposes

\begin{tabular}{|c|c|c|c|c|c|}
\hline Sr.No & Dimensions & Constructs & Mean & $\mathbf{N}$ & Std. Dev. \\
\hline \multirow{5}{*}{1} & \multirow{5}{*}{ Familiarity } & I am able to use Mobile & 4.19 & 300 & 0.410 \\
\hline & & I am able to use mobile very easily. & 4.39 & 300 & 0.616 \\
\hline & & I have good experience about mobile. & 4.43 & 300 & 0.728 \\
\hline & & I know about mobile based transaction. & 4.46 & 300 & 0.223 \\
\hline & & $\begin{array}{l}\text { Website of my bank is very user friendly to carry } \\
\text { transaction over mobile. }\end{array}$ & 4.51 & 300 & 0.429 \\
\hline \multirow{4}{*}{2} & \multirow{4}{*}{$\begin{array}{l}\text { Security \& } \\
\text { Privacy }\end{array}$} & Digital Wallet and Mobile banking is safe & 4.32 & 300 & 0.697 \\
\hline & & Service Provider keeps credentials safe \& secure & 4.23 & 300 & 0.813 \\
\hline & & $\begin{array}{l}\text { Fund Transfer through Digital Wallet and Mobile } \\
\text { Banking is safe \& secure. }\end{array}$ & 4.37 & 300 & 0.321 \\
\hline & & $\begin{array}{l}\text { Service provider keeps my all personal and } \\
\text { transaction details very safe and secure. }\end{array}$ & 4.11 & 300 & 0.481 \\
\hline \multirow{4}{*}{3} & \multirow{4}{*}{ Trust } & I trust on Digital transaction & 4.24 & 300 & 0.609 \\
\hline & & $\begin{array}{l}\text { I trust on Digital Wallet and Mobile banking } \\
\text { system }\end{array}$ & 4.43 & 300 & 0.567 \\
\hline & & $\begin{array}{l}\text { I trust on security features provided in Digital } \\
\text { Wallet and Mobile Banking }\end{array}$ & 4.39 & 300 & 0.356 \\
\hline & & I trust on my service provider. & 4.49 & 300 & 0.519 \\
\hline \multirow{3}{*}{4} & \multirow{3}{*}{ Easiness } & $\begin{array}{l}\text { Digital Wallet and Mobile banking web- } \\
\text { navigation is simple }\end{array}$ & 3.56 & 300 & 0.737 \\
\hline & & $\begin{array}{l}\text { Functioning of every platform is easy to } \\
\text { understand }\end{array}$ & 3.63 & 300 & 0.845 \\
\hline & & $\begin{array}{l}\text { All transaction of Digital wallet and Mobile } \\
\text { Banking are easy to perform }\end{array}$ & 3.96 & 300 & 0.816 \\
\hline \multirow{3}{*}{5} & \multirow{3}{*}{ Speed } & $\begin{array}{l}\text { Mobile Banking service is faster than traditional } \\
\text { banking system. }\end{array}$ & 4.60 & 300 & 0.719 \\
\hline & & $\begin{array}{l}\text { Digital wallet and Mobile banking pages loading } \\
\text { speedily }\end{array}$ & 3.66 & 300 & 0.757 \\
\hline & & $\begin{array}{l}\text { All applications of Digital wallet and Mobile } \\
\text { Banking loads faster }\end{array}$ & 3.85 & 300 & 0.869 \\
\hline \multirow{4}{*}{6} & \multirow{4}{*}{ Prestige } & It gives me lots of respect in the society. & 3.71 & 300 & 0.864 \\
\hline & & It helps me to maintain my status symbol. & 3.47 & 300 & 1.15 \\
\hline & & It is very much necessary for my living standard. & 4.24 & 300 & 0.887 \\
\hline & & $\begin{array}{l}\text { Everyone in my friend circle uses Mobile } \\
\text { Banking service. }\end{array}$ & 4.11 & 300 & 0.922 \\
\hline
\end{tabular}


Tabel 4. Distribution of Respondents (Region Wise)

\begin{tabular}{|c|c|c|c|c|}
\hline & \multicolumn{3}{|c|}{ Type of Bank } & \multirow{2}{*}{ Total } \\
\hline & Nationalized & Private & Co-operative & \\
\hline Pune & 33 & 42 & 0 & 75 \\
\hline Solapur & 57 & 14 & 4 & 75 \\
\hline Nashik & 34 & 36 & 5 & 75 \\
\hline Nagpur & 39 & 28 & 8 & 75 \\
\hline Total & 163 & 120 & 17 & 300 \\
\hline$\%$ & 54.33 & 40 & 5.67 & 100 \\
\hline
\end{tabular}

\section{Factor Analysis (Principal Component Analysis)}

To understand the adoption of digital wallet and mobile banking services, the researcher has used Principal Component Analysis. It is also called as Factor Analysis. This method is widely used to understand most influencing factors affecting on the adoption of digital wallet and mobile banking services. Before performing Factor Analysis, it is mandatory to check consistency of data. Here, researches used Kaiser-Meyer-Olkin (K-M-O) and Bartlett's Sphericity test to understand adequacy of the data for factor analysis.

Table 8.5 indicates that, in the present test the Kaiser-Meyer-Olkin (KMO) measure was 0.620. Bartlett's Sphericity test also found highly significant; Chi-square $=2666.355, \mathrm{df}=511$ with a significant of 0.000 it indicates that this data support for factor analysis and indicates that, factor analysis will appropriate with this data.

Tabel 5. Kaiser-Meyer-Olikn and Bartlett's Test of Sphericity

\begin{tabular}{llc}
\hline $\begin{array}{l}\text { Measure of Sampling Adequacy by } \\
\text { Kaiser- Meyer- Olkin (K-M-O) }\end{array}$ & 0.620 \\
\hline \multirow{3}{*}{$\begin{array}{l}\text { Bartlett's Test of } \\
\text { Sphericity }\end{array}$} & $\begin{array}{l}\text { Approximate } \\
\text { Chi-Square Value }\end{array}$ & 2666.355 \\
\cline { 2 - 3 } & $\begin{array}{l}\text { Degree of } \\
\text { Freedom }\end{array}$ & 511 \\
\cline { 2 - 3 } & Significance. & 0.000 \\
\hline
\end{tabular}

Initial communalities (Table 6) labelled as Initial are before extraction communalities and labelled as extraction are after extraction communalities. All the calculated communalities were high (above 0.325), which specifies that the extracted components represent all the variables well.

Tabel 6. Initial Communalities

\begin{tabular}{lcc}
\hline & Initial & Extraction \\
\hline I am able to use Mobile & 1.0000 & 0.614 \\
\hline I am able to use mobile very easily. & 1.0000 & 0.578 \\
\hline I have good experience about mobile. & 1.0000 & 0.558 \\
\hline I know about mobile based transaction. & 1.0000 & 0.541 \\
\hline $\begin{array}{l}\text { Website of my bank is very user friendly to carry transaction over } \\
\text { mobile. }\end{array}$ & 1.0000 & 0.325 \\
\hline $\begin{array}{l}\text { Digital Wallet and Mobile banking is safe } \\
\text { Service Provider keeps credentials safe \& secure }\end{array}$ & 1.0000 & 0.515 \\
\hline $\begin{array}{l}\text { Fund Transfer through Digital Wallet and Mobile Banking is safe \& } \\
\text { secure. }\end{array}$ & 1.0000 & 0.494 \\
\hline $\begin{array}{l}\text { Service provider keeps my all personal and transaction details very } \\
\text { safe and secure. }\end{array}$ & 1.0000 & 0.478 \\
\hline \begin{tabular}{l} 
I trust on Digital transaction \\
\hline
\end{tabular} & 1.0000 & 0.475 \\
\hline
\end{tabular}




\begin{tabular}{llc}
\hline & Initial & Extraction \\
\hline I trust on Digital Wallet and Mobile banking system & 1.0000 & 0.429 \\
\hline $\begin{array}{l}\text { I trust on security features provided in Digital Wallet and Mobile } \\
\text { Banking }\end{array}$ & 1.0000 & 0.437 \\
\hline I trust on my service provider. & 1.0000 & 0.873 \\
\hline Digital Wallet and Mobile banking web-navigation is simple & 1.0000 & 0.421 \\
\hline Functioning of every platform is easy to understand & 1.0000 & 0.883 \\
\hline $\begin{array}{l}\text { All transaction of Digital wallet and Mobile Banking are easy to } \\
\text { perform }\end{array}$ & 1.0000 & 0.744 \\
\hline Mobile Banking service is faster than traditional banking system. & 1.0000 & 0.493 \\
\hline Digital wallet and Mobile banking pages loading speedily & 1.0000 & 0.750 \\
\hline All applications of Digital wallet and Mobile Banking loads faster & 1.0000 & 0.489 \\
\hline It gives me lots of respect in the society. & 1.0000 & 0.456 \\
\hline It helps me to maintain my status symbol. & 1.0000 & 0.647 \\
\hline It is very much necessary for my living standard. & 1.0000 & 0.619 \\
\hline Everyone in my friend circle uses Mobile Banking service. & 1.0000 & 0.759 \\
\hline Extraction Method: Principal Component Analysis. & &
\end{tabular}

Tabel 7. Total Calculated Variance Explained

\begin{tabular}{|c|c|c|c|c|c|c|c|c|c|}
\hline \multirow[t]{2}{*}{ No. } & \multicolumn{3}{|c|}{ Initial Eigen Values } & \multicolumn{3}{|c|}{$\begin{array}{l}\text { Extraction Sums of Squared } \\
\text { Loadings }\end{array}$} & \multicolumn{3}{|c|}{$\begin{array}{l}\text { Rotation Sums of Squared } \\
\text { Loadings }\end{array}$} \\
\hline & Total & $\begin{array}{l}\text { Percentage } \\
\text { of Variance }\end{array}$ & $\begin{array}{l}\text { Cumulative } \\
\text { Percentage }\end{array}$ & Total & $\begin{array}{l}\text { Percentage } \\
\text { of Variance }\end{array}$ & $\begin{array}{l}\text { Cumulative } \\
\text { Percentage }\end{array}$ & Total & $\begin{array}{l}\text { Percentage } \\
\text { of Variance }\end{array}$ & $\begin{array}{l}\text { Cumulative } \\
\text { Percentage }\end{array}$ \\
\hline 1 & 4.115 & 11.205 & 11.175 & 4.125 & 11.125 & 11.235 & 2.468 & 7.642 & 7.456 \\
\hline 2 & 2.351 & 8.134 & 19.585 & 2.751 & 8.123 & 19.856 & 2.218 & 6.698 & 14.677 \\
\hline 3 & 2.356 & 6.212 & 25.458 & 2.676 & 6.630 & 25.768 & 2.224 & 6.464 & 21.568 \\
\hline 4 & 1.944 & 5.389 & 31.341 & 1.834 & 5.883 & 25.396 & 2.135 & 5.385 & 31.632 \\
\hline 5 & 1.735 & 5.012 & 36.789 & 1.745 & 5.656 & 31.267 & 1.897 & 5.054 & 36.734 \\
\hline 6 & 1.665 & 4.478 & 40.521 & 1.654 & 5.015 & 36.683 & 1.886 & 4.466 & 40.549 \\
\hline 7 & 1.578 & 3.849 & 43.428 & 1.877 & 4.865 & 41.282 & 1.679 & 3.478 & 43.832 \\
\hline 8 & 1.448 & 3.785 & 48.815 & 1.542 & 4.532 & 46.541 & 1.561 & 3.545 & 48.983 \\
\hline 9 & 1.276 & 3.574 & 51.434 & 1.315 & 4.518 & 49.856 & 1.432 & 3.614 & 51.547 \\
\hline 10 & 1.165 & 3.481 & 54.292 & 1.238 & 3.958 & 53.560 & 1.376 & 3.481 & 54.531 \\
\hline 11 & 1.107 & 3.395 & 57.658 & 1.086 & 3.762 & 57.461 & 1.252 & 3.357 & 57.654 \\
\hline 12 & 1.001 & 2.757 & 67.58 & & & & & & \\
\hline 13 & 0.987 & 2.456 & 74.65 & & & & & & \\
\hline 14 & 0.917 & 2.278 & 79.63 & & & & & & \\
\hline 15 & 0.889 & 2.067 & 81.36 & & & & & & \\
\hline 16 & 0.843 & 1.988 & 85.54 & & & & & & \\
\hline 17 & 0.786 & 1.785 & 87.69 & & & & & & \\
\hline 18 & 0.722 & 1.668 & 88.69 & & & & & & \\
\hline 19 & 0.657 & 1.518 & 90.65 & & & & & & \\
\hline 20 & 0.566 & 1.277 & 93.41 & & & & & & \\
\hline 21 & 0.432 & 1.116 & 97.76 & & & & & & \\
\hline 22 & 0.339 & 0.856 & 98.82 & & & & & & \\
\hline 23 & 0.269 & 0.781 & 100.0 & & & & & & \\
\hline
\end{tabular}


All the Eigen values associated with each linear component before and after extraction is shown in the table 8.7. The total variance is all the variables which is accounted for by that respect to the variable is measured by the Eigen value for a given factor.

The eigenvalue associated with each factor represent the variance explained by the particular linear component. In table 8.7, 'Initial Eigenvalues' indicates that;

$1^{\text {st }}$ Factor accounting $7.99 \%$ of variance in this model.

$2^{\text {nd }}$ Factor accounting $7.56 \%$ of variance in this model. $3^{\text {rd }}$ Factor accounting $6.88 \%$ of variance in this model.

$4^{\text {th }}$ Factor accounting $6.66 \%$ of variance in this model.

$5^{\text {th }}$ Factor accounting $5.80 \%$ of variance in this model.

$6^{\text {th }}$ Factor accounting $5.39 \%$ of variance in this model.

Table 8 indicates item wise loading of the construct and it's important in the present model. The table indicating that there is total communicative impact of 6 factors was $39.5 \%$ and first factor presenting impact of $7.78 \%$ however $6^{\text {th }}$ factor presenting $5.29 \%$ of impact in the model.

Tabel 8. Rotated Component Matrix

\begin{tabular}{|c|c|c|}
\hline It gives me lots of respect in the society. & 0.877 & \multirow{4}{*}{$\begin{array}{l}\text { 1.Prestige } \\
(7.99 \%)\end{array}$} \\
\hline It helps me to maintain my status symbol. & 0.760 & \\
\hline It is very much necessary for my living standard. & 0.745 & \\
\hline Everyone in my friend circle uses Mobile Banking service. & 0.754 & \\
\hline Mobile Banking service is faster than traditional banking system. & 0.667 & \multirow{3}{*}{$\begin{array}{l}\text { 2. Speed } \\
(7.56 \%)\end{array}$} \\
\hline Digital wallet and Mobile banking pages loading speedily & 0.579 & \\
\hline All applications of Digital wallet and Mobile Banking loads faster & 0.693 & \\
\hline I trust on Digital transaction & 0.888 & \multirow{4}{*}{$\begin{array}{l}\text { 3. Trust } \\
(6.88 \%)\end{array}$} \\
\hline I trust on Digital Wallet and Mobile banking system & 0.720 & \\
\hline $\begin{array}{l}\text { I trust on security features provided in Digital Wallet and Mobile } \\
\text { Banking }\end{array}$ & 0.644 & \\
\hline I trust on my service provider. & 0.610 & \\
\hline Digital Wallet and Mobile banking is safe & 0.778 & \multirow{4}{*}{$\begin{array}{l}\text { 4. Safety and Security } \\
\qquad(6.66 \%)\end{array}$} \\
\hline Service Provider keeps credentials safe \& secure & 0.690 & \\
\hline $\begin{array}{l}\text { Fund Transfer through Digital Wallet and Mobile Banking is safe \& } \\
\text { secure. }\end{array}$ & 0.794 & \\
\hline $\begin{array}{l}\text { Service provider keeps my all personal and transaction details very } \\
\text { safe and secure. }\end{array}$ & 0.486 & \\
\hline Digital Wallet and Mobile banking web-navigation is simple & 0.768 & \multirow{3}{*}{$\begin{array}{l}\text { 5.Easiness } \\
(5.80 \%)\end{array}$} \\
\hline Functioning of every platform is easy to understand & 0.710 & \\
\hline $\begin{array}{l}\text { All transaction of Digital wallet and Mobile Banking are easy to } \\
\text { perform }\end{array}$ & 0.826 & \\
\hline I am able to use Mobile & 0.723 & \multirow{5}{*}{$\begin{array}{l}\text { 6.Familiarity } \\
\text { (5.39\%) }\end{array}$} \\
\hline I am able to use mobile very easily. & 0.625 & \\
\hline I have good experience about mobile. & 0.611 & \\
\hline I know about mobile based transaction. & 0.499 & \\
\hline $\begin{array}{l}\text { Website of my bank is very user friendly to carry transaction over } \\
\text { mobile. }\end{array}$ & 0.727 & \\
\hline
\end{tabular}

Extraction Method: Principal Component Analysis.

Rotation Method: Varimax with Kaiser Normalization.

a. Rotation converged in 7 iterations. 


\section{Hypothesis Testing}

In this section we have tested the stated hypothesis using Chi Square Test for testing significant effect. Chi-square test is generally used to test the significant difference when there is more than three categories of the testing variable. After performing Hypothesis testing on stated variables, we received following calculations.

\section{Hypothesis 1: (Null Rejected)}

$\mathrm{H}_{1}$ : There is significant relationship between Security-Privacy \& adoption of digital wallet \& mobile banking.

These results indicates that there is a significant relationship between Security-Privacy \& adoption of digital wallet $\&$ mobile banking. (Chi - square with 3 degree of freedom $=56.93, p=0.000$ ). Here expected table value is 27.664 however actual calculated value is more than table value. Hence Null Hypothesis is rejected.

\section{Hypothesis 2: (Null Rejected)}

$\mathrm{H}_{2}$ : There is significant relationship between Trust $\&$ adoption of digital wallet \& mobile banking.

These results indicates that there is a significant relationship between Trust \& adoption of digital wallet \& mobile banking. (Chi - square with 3 degree of freedom $=66.34, p=0.000)$. Here expected table value is 37.109 however actual calculated value is more than table value. Hence Null Hypothesis is rejected.

\section{Hypothesis 3: (Null Rejected)}

$\mathrm{H}_{3}$ : There is significant relationship between Familiarity \& adoption of digital wallet \& mobile banking.

These results indicates that there is a significant relationship between Familiarity \& adoption of digital wallet \& mobile banking. (Chi - square with 3 degree of freedom $=43.42, p=0.000$ ). Here expected table value is 24.883 however actual calculated value is more than table value. Hence Null Hypothesis is rejected.

\section{RESULT AND DISCUSSION}

- It is found that Male was $69 \%$ whereas Female Mobile banking users was only 31\%. 54.33\% Mobile banking users are from Nationalized banks whereas 40\% from Private bank and only $5.67 \%$ from Co-operative banks.

- The overall responses regarding Determinants of Adoption of Mobile Banking and purposes of using it, researcher has extracted mean value of the responses and data shows that (Table 8.3), Familiarity dimensions was ranging from 4.19 to 4.51 , Security -Privacy dimension ranging from 4.11 to 4.37 , dimensions trust was ranging from 4.24 to 4.49 , dimension easiness was ranging from 3.56 to 3.96 , dimensions speed was ranging from 3.66 to 4.60 , dimensions prestige was 3.47 to 4.24 .

- Results of the factor analysis indicates that Familiarity, Security-Privacy, Trust, Easiness, Speed and Prestige are not having equal

Tabel 9. Results of Pearson Chi-Square Tests

\begin{tabular}{lcccc}
\hline \multicolumn{1}{c}{ Parameters } & $\begin{array}{c}\text { Calculated } \\
\text { Value }\end{array}$ & $\begin{array}{c}\text { Degree of } \\
\text { Freedom }\end{array}$ & $\begin{array}{c}\text { Assy. Sig } \\
\text { (2-sided) }\end{array}$ & Result \\
\hline $\begin{array}{l}\text { Security-Privacy \& adoption of } \\
\text { digital wallet \& mobile banking. }\end{array}$ & 56.93 & 3 & 0.000 & Null Rejected \\
\hline $\begin{array}{l}\text { Trust \& adoption of digital wallet } \\
\text { \& mobile banking. }\end{array}$ & 66.34 & 3 & 0.000 & Null Rejected \\
\hline $\begin{array}{l}\text { Familiarity \& adoption of digital } \\
\text { wallet \& mobile banking. }\end{array}$ & 43.42 & 3 & 0.000 & Null Rejected \\
\hline
\end{tabular}


importance in the adoption of mobile banking services among the customers. Actually factor analysis has given 6 groups of factors i.e. 1. Prestige (7.99\%), 2. Speed (7.56\%), 3. Trust (6.88\%), 4. Safety and Security (6.66\%), 5. Easiness (5.80\%), 6. Familiarity (5.39\%).

- Result of Hypothesis testing shows that there is a significant relationship between SecurityPrivacy, Trust \& Familiarity with adoption of Digital Wallet and Mobile banking services among rural customers of Maharashtra state, INDIA.

\section{MANAGERIAL IMPLICATIONS}

Recetly India have proved rapid growth in most of the business areas and this journey is still in process. In Information Technology, it seems to be huge improventment especially in the urban regions. Still, it is not that much in rual as compared to the urban areas. With the increase in smart devices, growth in internet speed and innovations in the technology, it is important to understand the approach of rural bank customer for digital wallet and mobile banking adoption. This study has several implications for mareters. Firstly, financial institutions who are offering digital wallet and mobile banking services will get an idea abot important factors from rural customer's point of view. How rural customer is adopting the sercive and what is in his mind to become techno-savvy for digital wallet and mobile banking adotion. Banking institutions should work on factors such as Familiarity, Trust, Security-Privacy, Easiness, Speed, Convenience etc because still there is lot of ambiguities in the mind of rural bank customer for adopting such services. Providing these services along with increase in spees of application with securing data with privacy will improve adoption usage in Indian context. .

\section{CONCLUSION}

This study tried to understand and indentify rural bank customer's opinion regarding digital wallet and mobile banking adotion. This study concludes that there is rapid development and usage in Information Technology services in India but rural region is not that much progressed. Rural customer feels that Security-Privacy, Trust and Familiarity having significant relationship for the adotion of digital wallet and mobile banking services. Finally this study concludes that the qualitative factors such has Prestige, Speed, Trust, Safety \& Security, Easiness and Familiarity has major influence on rural customer for the adopting of Digital Wallet and Mobile banking services offered from financial institution in Indian context.

REFERENCES

Anitha. K, Saranya. J, Dr. S.Vasantha (2013), "An Exploratory Study on Usage of Technology, in Banking Sector" Vol. 2, Issue 11,pp.6487-6494

Georgia Giordani (2012), Essays on the Econometric Analysis of Electronic banking in Greece. The thesis is submitted in partial fulfillment of the requirements for the award of the degree of Doctor of Philosophy of the University of Portsmouth. May 2013.

Hari Mohan, Norani Ahmad, Quah Chi Kong, Chiam Tzeh Yew, Jimmy Liew, Nik Kamariah Nik Mat (2013), Determinants of the Internet Banking Intention in Malaysia, American Journal of Economics , Volume.3, No.3, pp.149-152

Padashetty and Kishore SV (2013), "An Empirical Study On Consumer Adoption of Mobile Payments In Bangalore City -A Case Study" Vol.-IV, Issue-1(1), pp. 83-94

Parakh (2014), An Empirical study of consumer's perspective on internet banking adoption with reference to western Maharashtra. A Thesis submitted to Solapur University, Solapur for the Degree of Philosophy in Commerce \& Management under the faculty of Commerce. August 2014. 
Parakh S and Suryawanshi K (March 2018), A rural customer's preference on Mobile Banking Services: Case of Satara District, Published in Asian Journal of Multidimensional Research, ISSN: 2278-4853, March 2018, Volume 7, Issue 3.

Parakh S.D and Barbole A. N (March 2014), Internet banking and factors affecting On adoption of internet banking: A Review of literature, Published in Golden Research Thoughts: International Journal, ISSN 2231-5063, Volume 3, Issue 9.

Parakh S.D and Barbole A. N (April 2013), The study of consumer's perspective About internet banking: empirical evidence From western Maharashtra, Published in Indian Stream Research Journal, ISSN - 2230 - 7850, Volume 3, Issue 3.

Perkins, Ed-Zilla Daniel, Annan, Jonathan (2013), Factors affecting the Adoption of Online Banking in Ghana: Implications for Bank Managers, International Journal of Business and Social Research (IJBSR), Volume -3, No.-6, pp. 94-108

Somkiat Mansumitrchai, Husam-Aldin N. AL-Malkawi (2011), Factors Underlying the Adoption of Online Banking by Mexican Consumers, International Journal of Business and Management Vol. 6, No. 9, pp. 155-169

Sharma (2011), "Issues \& Challenges in Mobile Banking In India: A Customers' Perspective" Vol. 2, No. 2, pp. 350-369

Sharma (2011): Mobile Banking As Technology Adoption And Challenges” Vo. 1, Issue. 6, pp. 147-157.

http://www.rbi.org.in 